\title{
EFFECTIVENESS OF THE USE OF ICT-BASED LEARNING MEDIA WITH POWER POINT AND SOCRATIVE (STUDENT RESPONSE SYSTEM) APPLICATIONS FOR CLASS $X$ SOCIOLOGY LEARNING OF SOCIAL SCIENCE OF HIGH SCHOOL 1 KANDANGAN
}

\author{
By: \\ Suyud Prabudi, S.Sos \\ High School 1 Kandangan \\ e-mail: suyud73@gmail.com
}

\begin{abstract}
The background of this research is the lack of learning media used by educators in the learning process. This study aims to determine the effectiveness of power point and socrative (Student Response System) to increase student interest and learning outcomes. The formulation of the problem in this study is 1) Is the interest in learning a variety of social symptoms in society for students of Class $X$ Social Sciences High School 1 Kandangan 2017/2018 Academic Year can be improved by utilizing Power Point and Socrative (Student Response System). 2) Are the learning outcomes of various social symptoms in the community for students of Class $X$ Social Sciences in Kandangan Middle School 2017/2018 Academic Year can be increased by utilizing Power Point and Socrative (Student Response System). 3) How is the development of learning a variety of social symptoms in the community by utilizing Power Point and Socio (student response system) in students of Class $X$ Social Sciences Public High School 1 Kandangan 2017/2018 Academic Year. Data collection techniques used in this study consisted of tests, observations, questionnaires, documentation, interviews using interview guidelines, and field notes. This research is classroom action research conducted in two learning cycles with stages including action planning, action implementation, observation / evaluation of actions, and reflection. The results showed that there was 1) an increase in student learning interest, namely from $77.78 \%$ interested in high learning in Cycle I to $86.11 \%$ interested in high learning in cycle II, 2) improvement in student learning outcomes that is from $72.22 \%$ with classical completeness 68.75 in Cycle I to $91.67 \%$ with 93.75 classical completeness in cycle II. The use of powerpoint and socrative (student response system) can increase interest and learning outcomes of various social symptoms in society.
\end{abstract}

Keywords: Media power point, socrative, interest in learning, learning outcomes

\section{INTRODUCTION}

Teaching and learning activities in class X Social Sciences Public High School 1 Kandangan, Kediri Regency, found several problems such as lack of student involvement in the learning process. This resulted in students becoming less concentrated, less focused and less interested in the material delivered by the teacher. Students also often miss the material when recording the material delivered by the 
teacher and the concentration of students is divided. Students need teaching materials that are delivered by the teacher in the classroom, while the teacher must achieve the objectives of the learning. The material received by students does not fully describe the actual knowledge, because of the limitations of a teacher. In addition, the knowledge conveyed by the teacher is still often conventional.

Conventional learning media causes the transfer of knowledge from student teachers without any feed back from students, therefore learning models like this tend to teach students only to listen without any effort to explore their own knowledge and learn to think critically in facing a problem because the material received in learning process like that is pure with memorization without meaningful meaning from a process they have done.

The development of information and communication technology has brought enormous changes to the advancement of the world of education. Along with these developments learning methods also experience many developments, both personal learning methods, learning media or learning processes. The form of the development of information technology lied in the world of education is a Power Point and socrative learning media (Student Response System).

Power Point and socrative (Student Response System) is an innovation that has a very large contribution to changes in the learning process, where the learning process is no longer just listening to the material description from the teacher but students also make other interests such as observing, doing, demonstrating and others. Teaching materials can be visualized in a variety of formats and forms that are more dynamic and interactive so that students will be motivated to engage further in the learning process. In reality the use of Power Point and Socrative (Student Response System) as a learning medium is still rarely done in High School 1 Kandangan, Kediri Regency. For this reason, the writer wants to use IT (Information Technology) based learning media as a learning media that can support student learning outcomes in High School 1 Kandangan, Kediri Regency.

Use of media Power point is done by packaging teaching material in an interesting, concise, concise and effective manner. Power point has a custom animation facility that is very complete, so it can create an active learning environment, fun, help students understand difficult subject matter, and help teachers teach complex material, and make abstract sociological material more real so that it is easily absorbed by students. Socio media, a student response system, which allows teachers to make quizzes or interactive games and involve students directly or in real time. With 
Socrative, Teachers can make quizzes with multiple choice models, right or wrong, and short entries; or, if you want to make the quiz more fun and challenging, the teacher can also choose the game format, namely Space Race. In this game, students are divided into several teams and compete by answering questions. Student answers will be calculated automatically and presented in the form of Excel files or Google Spreadsheets. Did the students' understanding of the material increase after the quiz was held? After the quiz is finished, students will get an Exit Tickets containing a statement about what has been learned and what students need in the next session, so that the teacher can see the extent to which students understand what is being learned. This socrative media can be run on devices based on Android, both tablets and smartphones. This is in line with current technological developments.

Based on the explanation above, it is considered necessary to study more deeply by conducting a study entitled "Increasing Interest and Learning Outcomes of Various Social Symptoms in Communities with the Utilization of Socrative Power Points in Student Class $X$ Social Sciences in Senior High School 1 Kandangan Academic Year 2017/2018 "

\section{LITERATURE REVIEW}

The media that can be used in the learning process is Power Point and Socrative (Student Response System). Microsoft Power Point is a computer program devoted to presentations. Microsoft Power Point is a development from other Microsoft. The Microsoft Power Point lication was first developed by Bob Gaskin and Dennis Austin as the presentator for a company called Forethought, Inc. which they later renamed Power Point. (Aqila Smart, 2012: 65).

Socrative (Student Response System) is an online lication. Using the Socrative (Student Response System) is very helpful for teachers in teaching and learning activities, which allows teachers to make quizzes or interactive games and involve students directly or in real time. The use of Socrative allows teachers to design various interests and control the flow of quizzes. Student response reports can be viewed online as a Google spreadsheet or as an excel file. Socrative (Student Response System) and technology-based systems can increase student involvement (Terrion and Aceti, 2012). Socrative (Student Response System) has been widely used before through a tool called clickers that shows a positive impact on student involvement (Blasco et al., 2012), where students can give feedback directly to lecturer questions, but clickers have expensive initial costs, besides that its function is limited. This results 
in the search for tools or software that can be used via a smartphone either through a mobile connection or Wi-Fi internet connection.

\section{RESEARCH METHODS}

Classroom action research was conducted at High School 1 Kandangan, Kediri, East Java, Class X Social Sciences, 2017/2018 academic year, Jalan Hayam Wuruk No. 96 Kandangan Kediri Regency, East Java. In this study the research was the use of powerpoint and socrative media (student response system) on increasing interest and learning outcomes of various social symptoms in the community in students of Class $X$ Social Sciences in Senior High School 1 Kandangan in the academic year 2017/2018. The data needed in classroom action research comes from written documents and resource persons. Written documents in the form of a list of values, teaching journals, and student assignments. The intended resource persons are students, teachers, and collaborators.

Data collection techniques, which will be used in this study consist of tests, observations, questionnaires, documentation, interviews using interview guidelines, and field notes. Test the credibility of data or trust in the results of qualitative research, among others, carried out by an extension of observation, increased perseverance, triangulation, discussion with colleagues, negative case analysis and member check.

In this classroom action research, data is analyzed since the learning action is carried out and developed, during the reflection process, until the report preparation process. This classroom action research was analyzed using qualitative and quantitative data analysis. In classroom action research, research procedures are carried out using action cycles (recycling). Recycling in research begins with planning, action (observation), observing (observation), and reflecting (Reflection), and so on until the expected increase is achieved, Hopkins in Arikunto (2008: 14). The procedure for implementing class actions can be seen in the chart below: 


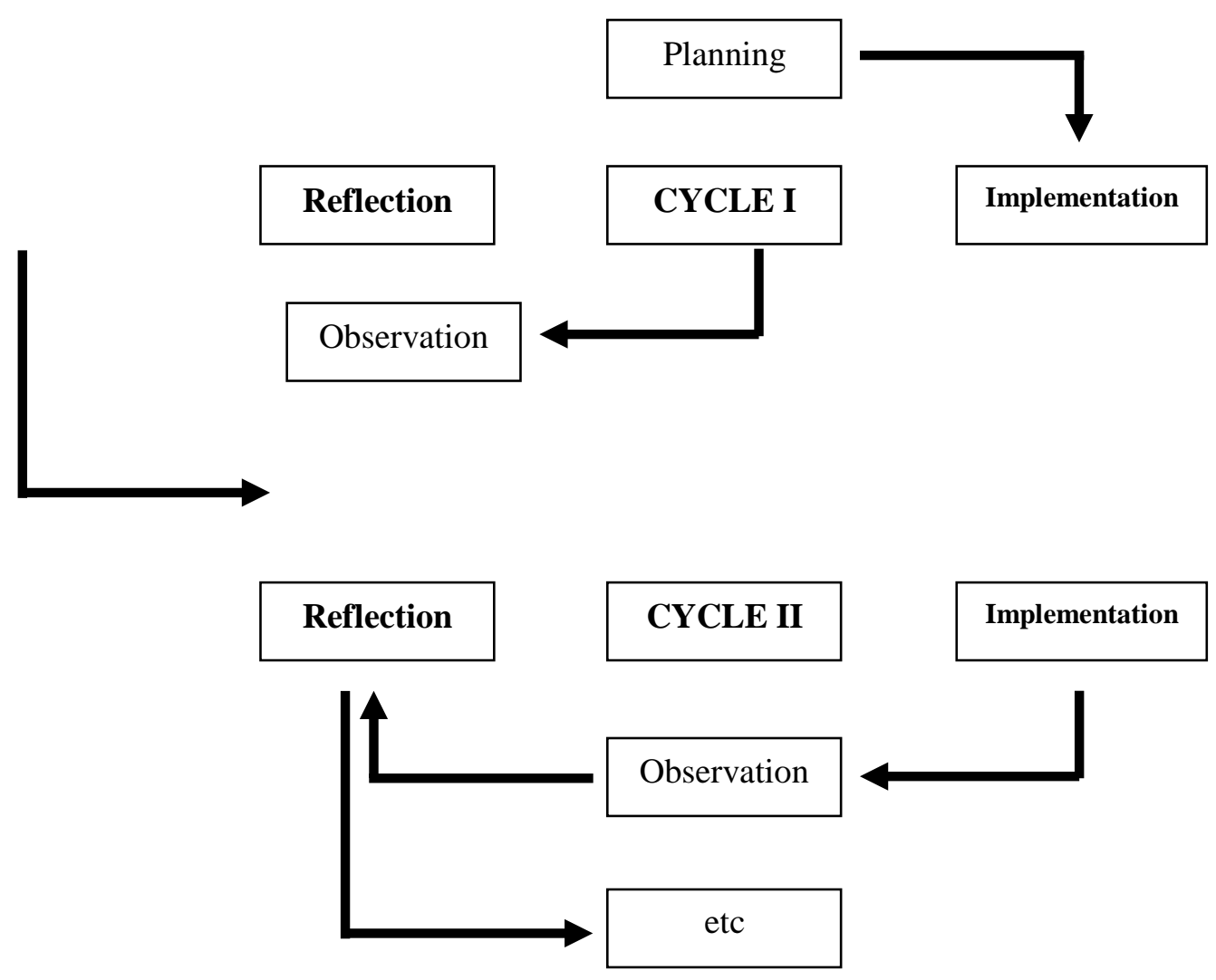

C Figure: Procedure for the research cycle, adopted from Arikunto (2010: 17)

y

$\mathrm{cl}$

e

I Based on the analysis of student learning outcomes obtained from student learning

outcomes before the implementation of the action, researchers can identify students' difficulties in 
understanding learning various social symptoms in society. From here finally the researcher compiled the procedure for implementing class action research.

Cycle II

In the implementation of the second cycle is an improvement of the results of reflection that has been done in cycle I. Cycle II is carried out in four stages of activities, namely planning, implementation, observation, and reflection.

\section{RESEARCH RESULTS AND DISCUSSION RESULTS}

Pre-cycle

Based on the final results assessment, the learning outcomes of 36 students were only 9 people (25\%) that were completed, and the remaining 27 students (75\%) were not completed with a class average score of only 68.31, this can be seen from the student pre-test test results those who have not reached the minimum completeness criteria set by the school are 75 .

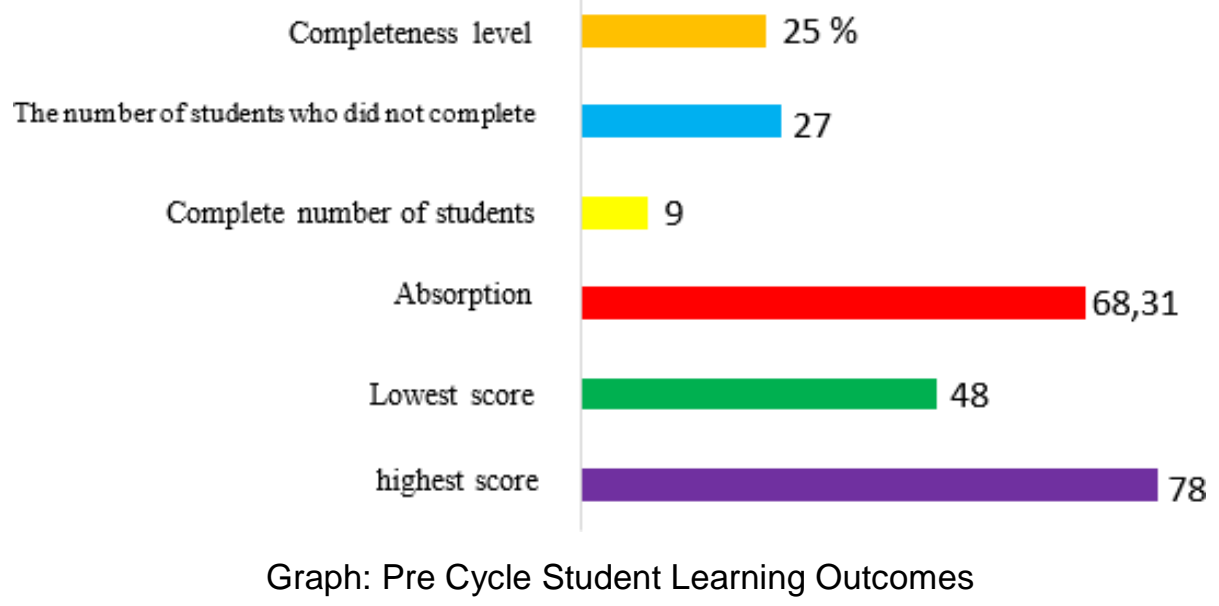

To find out the interest of students learning various social symptoms in society, researchers distributed questionnaires to 36 Calss $X$ Social Sciences students. Of the 36 students, there were 5 students (13.89\%) whose interest in learning was high, while 31 students (86.11\%) were interested in moderate learning.

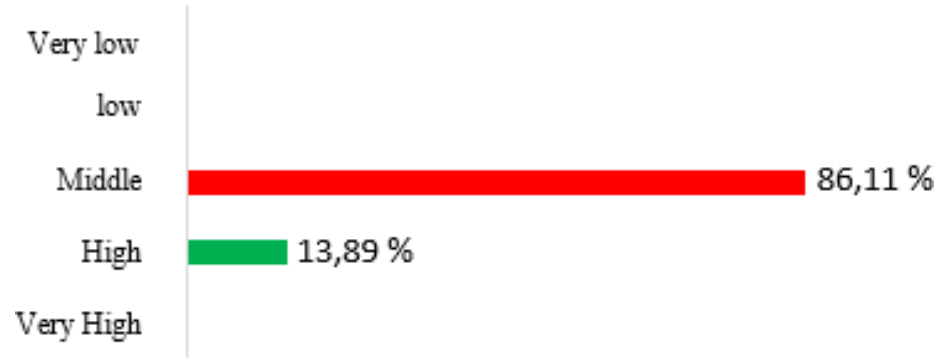

Graph: Pre-Cycle Student Interests 
Students experience learning difficulties because of several reasons, including boring and uninteresting teacher explanations, the explanations are only abstract, making them unable to understand the material. According to students all this time the teacher only gave a brief explanation, gave an explanation of the material being studied, students were given assignments, then collected them. The student's work is given a value without any feedback or explanation why it gets good or less.

Selection of Power Point and socrative media (Student Response System). Media Power Point can explain abstract explanations to be concrete and interesting to increase students' interest in learning, while socrative (Student Response System) is an lication that provides online-based tests based on Android phones. This was chosen to make students see that technology can be used as an innovative way of learning.

\section{Cycle I}

Based on the results of the assessment carried out by the researcher, student learning outcomes can be found that from 36 students 26 people (72.22\%) were completed (able to reach minimum completeness criteria 75), while the remaining 10 people $(27.78 \%)$ were not completed. The average grade shows that absorption is 74.69 ,

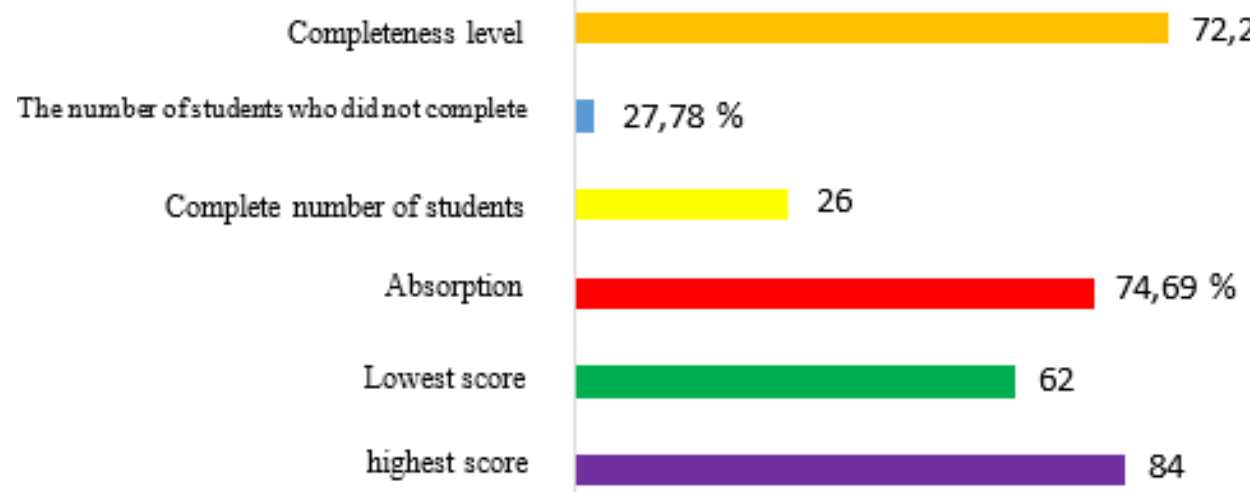

while classical completeness reaches 68.75 .

Graph: Student Cycle I Learning Outcomes

Based on the results of the learning interest questionnaire distributed to students after the implementation of the first cycle, it was found that most students, 28 people $(77.78 \%)$ were interested in high learning, 3 people (8.33\%) were interested in moderate learning, and the remaining 5 people (13.89\%) were very interested in learning high. This shows that there has been an increase in student interest in learning using powerpoint and socrative media compared to before the action. 


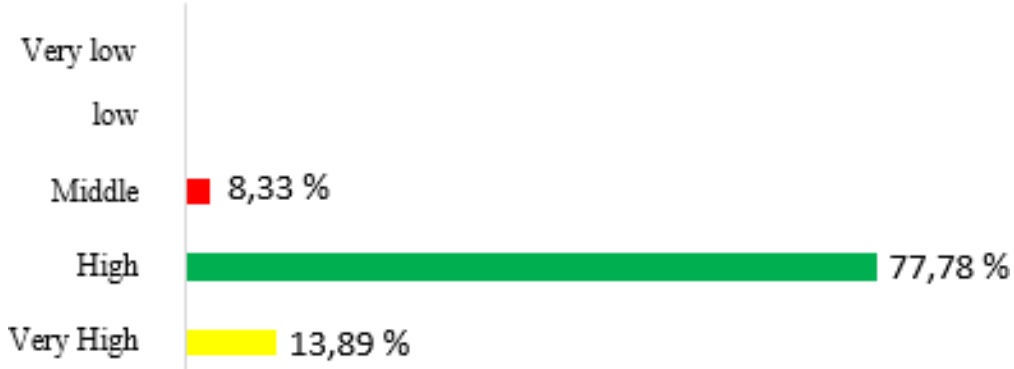

Graph: Cycle I Students' Interest in Learning

Based on the results of observations during the learning process, discussions with students, and collaborators, and analysis of learning outcomes can be concluded that in general, learning activities have taken place in accordance with planned learning activities that can increase student interest and learning outcomes. However, it has not been able to meet the indicators of the success of the actions that have been determined because the interest of most students (> 85\%) is not yet included in the high category, the level of classical completeness has only reached 68.75.

Based on the results of the reflection above, the thing that must be updated is the content or content that is in the powerpoint media, so the form of the question is socrative, so that students can be more focused and interested in the material being taught. As much as possible reduce the presentation of excessive textual material on each slide and avoid reading the slides. When the verbal presentation takes place we try to provide the subjects with a brief explanation so that students can be active and think critically.

Cycle II

Student learning outcomes can be seen that from 36 students as many as 33 people (91.67\%) have been completed and are able to reach minimum completeness criteria 75 , while the remaining 3 people (8.33\%) have not been completed. The average grade shows that absorption is 80.25 , while classical completeness reaches 93.75 .

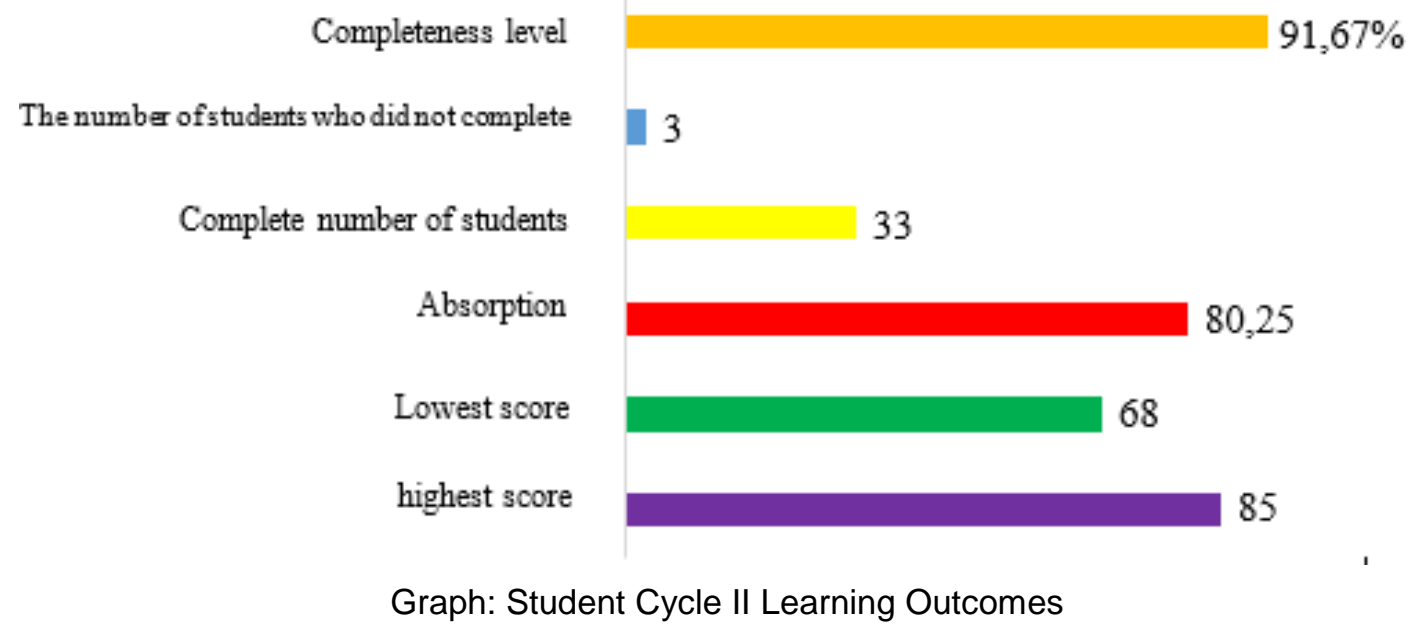


Thus the action in this second cycle has been able to meet the indicators of the success of the actions that have been set

Based on the results of the learning interest questionnaire distributed to students after the implementation of the second cycle, it was found that there were 4 people (11.11\%) interested students very high. Most students, 31 people (86.11\%) were interested in learning high, 4 people (11.11\%), and the remaining 1 person $(2.78 \%)$ was interested in moderate learning.

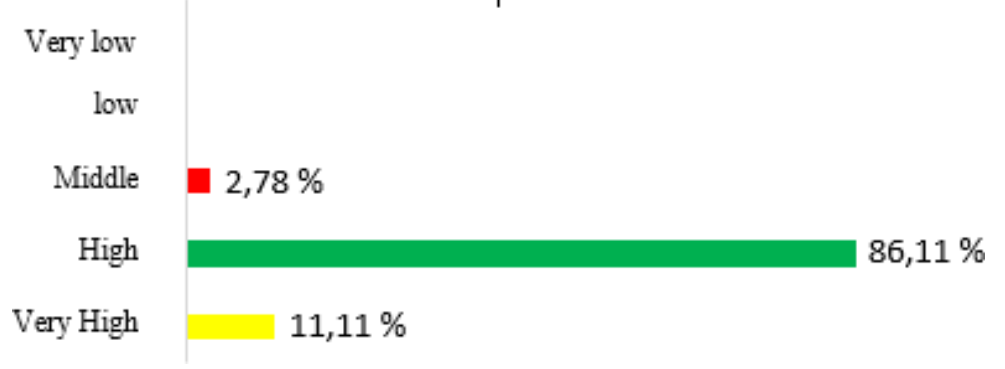

Graph: Cycle I Students' Interest in Learning

This shows that there has been an increase in students' interest in learning in learning various social symptoms in society compared to before the action and in the first cycle.

Based on the results of observations of the teaching and learning process, it ears that the teacher has taught according to the lesson plan made. The learning process in the classroom has been able to increase student interest and learning outcomes. The use of powerpoint media is useful in the learning process in the classroom, namely: 1) Learning media can clarify the presentation of messages and information so as to facilitate and increase interest and learning outcomes; 2) Learning media can improve and direct children's attention so that it can lead to motivation to learn, more direct interaction between students and their environment, and the possibility of students to learn on their own according to their abilities and interests; 3 ) Learning media can overcome sensory, space, and time limitations; 4) Learning media can provide students with similar experiences about the events in their environment, and enable direct interaction with teachers, the community, and their environment.

\section{DISCUSSION}

\section{Increased Interest in Student Learning in Learning Various Symptoms of Social In Society}

Student interest increases after learning is done using powerpoint and socio media. On the precursors of students' interest in learning in the high category is $13.89 \%$ and the moderate category is as much as $13.11 \%$, which is 31 students from 36 students. This is because students are less interested and bored with classroom learning activities, where learning is lecture without student involvement. After the action in the first cycle, there began to be an increase in the interest of high 
students $77.78 \%$ even though it was not yet above $85 \%$. While student interest is $8.33 \%$, which is 3 students and student interest categories are very high at $13.89 \%$.

Indicators of the students' interest in learning ear from their enthusiasm to take part in learning, answer questions asked by the teacher, ask questions, also timeliness in doing assignments. This was not only revealed from the results of observations and field notes during the learning process, but also the results of questionnaires. This is in accordance with three indicators of the interest in learning delivered by Slameto (2003), namely (a) the presence of attention, (b) the existence of attraction, and (c) the existence of pleasure.

The use of Powerpoint and socrative media, thus has been able to answer the demands of the National Education Standards Chapter IV article 19 paragraph 1, namely "the learning process in educational units is held interactively, inspirational, fun, challenging, motivating learners to actively participate, and providing sufficient space for initiative, creativity, and independence in accordance with the talents, interests, and physical and psychological development of students' students ".

\section{Improving Student Learning Outcomes in Learning Various Symptoms of Social In Society}

Increasing student learning outcomes from pre-cycle to cycle I and cycle II in detail are: 1) The highest score that students achieve is 78 at the end of cycle II to 85; 2) The lowest pre-cycle value is only 48 at the end of cycle II to 68; 3) Absorption in the pre cycle only 68.31 at the end of cycle II has become 80.25 ; 4) The number of students who completed it rose sharply from only 9 people in pre-cycle to 33 people, on the contrary the number that was not completed from 27 people on pre-cycle became only 3 people in cycle II; 5) The level of classical completeness from pre-cycle is only $25 \%$ to $91.67 \%$ at the end of cycle II.

In accordance with the indicators of success of the actions set out in this study, namely (a) interest in learning $85 \%$ of students must be in the high or very high category, (b) minimum absorption capacity o\& 75, and (c) classical completen ess $\geq$ $85 \%$ then this class action research it has been declared successful. The success of this action as well as proving that the formulated hypothesis is the use of powerpoints and socrative (student response system) can increase interest and learning outcomes of various social symptoms in society.

\section{Learning Development Various Symptoms of Social In Society}

There are several developments that must be considered in the use of powerpoint media so that the learning process becomes more interesting and gives a pleasant and professional impression to the teacher: 1) Use of a consistent design. This can be done using a slide master, so that layouts, fonts, bulleting, and slide animation changes become consistent until the end of the presentation. 2) 
Limit the new number of slides. Too many rows in the slide cause the slide to become too full, so the text becomes small. As a result, students will not digest the information in the slide. Deliver the main points in each slide, then the teacher must develop when explaining and students will be more involved in learning. 3) The use of contrasting text and background colors so that students can read them well. 4) Avoid using animation and excessive sound effects. If it's excessive, it causes the student to become unable to concentrate with the lesson. 5) Use of hyperlinks, create buttons that directly deliver on certain slides, so you can jump forward or backward without having to go through slide by slide.

The use of socrative in learning the various social symptoms in society is a form of e- learning technological innovation that can be done by teacher and student cooperation. The use of national AP can be carried out during school hours or outside of school hours. For example, students will be given practice questions or quizzes and other assignments that are homework assignments, students can do the task in real time outside of class hours. This is very effective in involving students in the learning process, time can be more flexible and the use of paper can be minimized.

\section{CONCLUSION AND SUGGESTION Conclusion}

The interest in learning various social symptoms in the community for students of Class X Social Sciences High School 1 Kandangan of 2017/2018 Academic Year can be improved by utilizing PowerPoint and Socrative (Student Response System). This increase can be seen from the large number of students whose learning interest increases. On the precursors of students' interest in learning in the high category is $13.89 \%$ and the moderate category is as much as $13.11 \%$, which is 31 students from 36 students. After the action in the first cycle, there began to be an increase in the interest of high students $77.78 \%$ even though it was not yet above $85 \%$. While student interest is $8.33 \%$, which is 3 students and student interest categories are very high at $13.89 \%$.

Learning outcomes of various social symptoms in the community for students of Class X Social Sciences in High School 1 Kandangan of 2017/2018 Academic Year can be improved by utilizing Power Point and Socrative (Student Response System). This increase can be seen from the absorption capacity of the cycle of only 68.31 at the end of cycle II to 80.25. And there was an increase in classical completeness from prasiklus, only $25 \%$ to $91.67 \%$ at the end of cycle II.

Development of learning various social symptoms in society by utilizing Power Point and Socio (student response system) for students of Class $X$ Social Sciences in High School 1 Kandangan of 2017/2018 Academic Year, can be done: 1) Use of Power Point media should be with a consistent design, limit the new number of each slide, the use of text colors and contrasting 
backgrounds, avoid using animation and excessive sound effects and the use of hyperlinks. 2) Historical use (student response system) can be an idea to involve students in learning. Student satisfaction is shown when the teacher shows the results of their assignments on the LCD projector in class. The teacher must always make several improvements to the question or task question, so that students can enjoy and feel enthusiasm in doing the task.

\section{Suggestion}

Suggestions from the results of this study are that it needs to be disseminated more broadly, sociology teachers should make use of instructional media and ropriate learning strategies as a culture to increase student interest and learning outcomes. Learning media that can help concretize abstract things in learning. Without the right strategy, a learning media will not be able to increase student interest and learning outcomes to the fullest.

\section{REFERENCE}

Arikunto, Suharsimi. 2010. Prosedur Penelitian Suatu Pendekatan dan Praktik. Jakarta: Rineka Cipta.

Arsyad, Azhar. 2011. Media Pembelajaran. Jakarta. Raja Grafindo Persada.

Awdeh, M., Mueen, A., Zafar, B. \& Manzour, U. 2014. Using Socrative and smart phones for the support of collaborative learning. International Journal on integration Technology in education 3(4), 18-24.

Aqib, Zainal. 2007. Penelitian Tindakan Kelas Untuk Guru. Bandung: Yrama Widya

Bartsch, R. A., and K. M. Cobern. 2003. Effectiveness of PowerPoint Presentation in Lectures.

Computers \& Education (Vol. 41) 77-86.

Daryanto, 2010. Media Pembelajaran: Peranannya Sangat Penting Dalam Mencapai Tujuan Belajar. Yogyakarta: Gava Media.

Nasution, S. 1997. Berbagai Pendekatan dalam Proses Belajar Mengajar. Jakarta: PT Bumi Aksara.

Sardiman. 2005. Interaksi dan Motivasi Belajar Mengajar. Jakarta : PT. Raja Grafindo Persada Putra, Agastya. 2012. Penerapan Model Pembelajaran Ceramah Berbantuan Media Pembelajaran

Berbasis Multimedia Untuk Meningkatkan Hasil Belajar PKn Siswa. Skripsi (tidak diterbitkan). Jurusan Pendidikan Pancasila dan Kewarganegaraan , FIS Undiksa. Singaraja.

Trianto. 2007. Model-model pembelajaran inovatif berorientasi konstruktivistik. Surabaya: Prestasi Pustaka Publizher.

Undang-Undang Republik Indonesia Nomor 20 Tahun 2003 Tentang Sistem Pendidikan Nasional. Bandung: Citra Umbara 